\title{
A Roman Shroud and its Demotic Inscriptions in the Museum of Fine Arts, Boston
}

\author{
Christina Riggs And Martin Andreas Stadler
}

A Roman Period shroud in the Museum of Fine Arts, Boston (accession no. 54.993; figs. 1-3) is an unusual example of funerary art from this era because of its Asyut provenance, its three Demotic inscriptions, and the style and iconography of its painted decoration, which includes both Egyptian scenes and a naturalistic portrait of the deceased woman. ${ }^{1}$ This study considers the artistic and textual evidence of the shroud in order to explore its dating and its relationship to funerary art and practices in Roman Egypt. ${ }^{2}$

\section{Description and Provenance}

The upper portion of the shroud depicts the head, chest, and arms of a woman painted in the naturalistic classical idiom, with her face turned slightly to her left. At the bottom of the shroud are her slender ankles and sandal-clad feet, which lie parallel to each other and are portrayed as if viewed from a vantage point above. When the shroud was in place on the corpse, these painted feet probably rose at an angle away from the body due to the natural projection of human feet, and the artist has taken this into account in the design of the shroud. ${ }^{3}$

The central section of the shroud consists of two register-ordered Egyptian scenes that function like a screen or covering to conceal the body of the dead woman. In contrast to the portrait above and the feet below, these scenes use Egyptian compositional forms and conceptual, rather than

\footnotetext{
${ }^{1} \mathrm{H} 1.905 \mathrm{~cm}$, W $47.0 \mathrm{~cm}$, as assembled. H of Fragment $1,27.0 \mathrm{~cm}$. The shroud was purchased from the sale of antiquities belonging to the Cairo dealer Albert Eid and given to the Egyptian department as a gift from the Class (now School) of the Museum of Fine Arts during the chairmanship of Mrs. A. L. Devens. Bibliography: K. Parlasca and H. Seemann, Augenblicke. Mumienporträts und ägyptische Grabkunst aus römischer Zeit (Frankfurt am Main, 1999), 228 (no. 137); S. D'Auria, P. Lacovara and C. H. Roehrig, Mummies and Magic. The Funerary Arts of Ancient Egypt (Boston, 1988), 204-5 (no. 154), entry by L. Corcoran; K. Parlasca, Ritratti di Mummie, Repertorio d'arte dell'Egitto greco-romano, Serie B, Vol. II (Rome, 1977), 66 (no. 392 ; mistakenly as from the "Ede" Collection), pl. 96, 3; C. C. Vermeule and M. Comstock, Greek and Roman Portraits 470 BC-AD 500 , Boston: Museum of Fine Arts (1972; 2nd revised ed.), fig. 46; K. Parlasca, Mumienporträts und verwandte Denkmäler, Wiesbaden: Steiner (1966), 46 n. 198 (no. 4), 186-87, 239 (no. 202), pl. 43,1; W. S. Smith, Ancient Egypt as Represented in the Museum of Fine Arts, Boston, 4th ed. (Boston, 1960), 188 with fig. 127 (portrait only); C. Vermeule and M. Comstock, Greek and Roman Portraits 470 BC-AD 500, 1st ed. (Boston, 1959), fig. 45; Museum of Fine Arts, Boston, Annual Report 1954, 8-9.

${ }^{2}$ In what follows, Christina Riggs is responsible for the description and discussion of the shroud and its portrait and Martin Andreas Stadler for the edition of the Demotic texts. The authors are grateful to the Department of Ancient Art of the Museum of Fine Arts, Boston, for permission to publish the shroud, and in particular to Lawrence Berman for his assistance. We also thank B. Borg, R. R. R. Smith, and K.-Th. Zauzich for their advice.

${ }^{3}$ For the representation of angled or projecting feet on mummies and coffins of the Roman Period, compare the coffin of Teüris (D. Kurth, Der Sarg der Teüris. Eine Studie zum Totenglauben im römerzeitlichen Ägypten (Mainz, 1990)), a shroud from Middle Egypt (Parlasca and Seemann, Augenblicke, 92-97, 310-13 (no. 206, now Louvre E 32634)), and the mummy of Artemidora, in Ancient Faces. Mummy Portraits from Roman Egypt, ed. S. Walker (New York, 2000), 132-35 (no. 85) [hereafter Ancient Faces (New York)].
} 


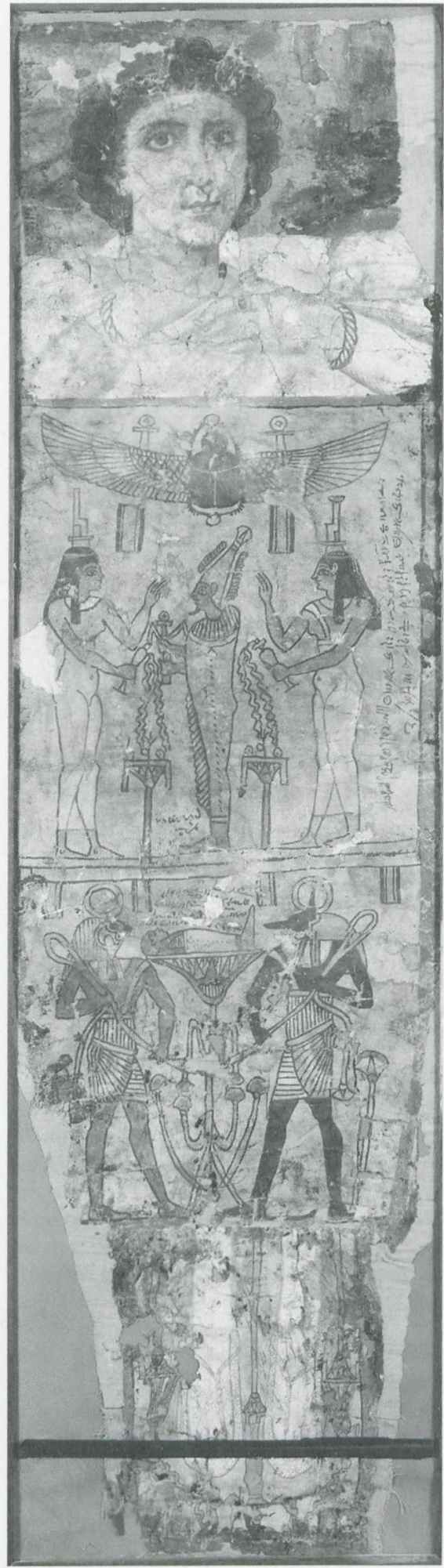

Figure 1. The shroud of Ta-sheret-Horudja, as originally mounted in the 1950s. Boston Museum of Fine Arts MFA 54.993. illusionistic, renditions of human figures. It is difficult to judge whether one, two, or more artists were responsible for the design and decoration of the shroud. Although it is feasible that one artist executed the classical portrait and another the Egyptian elements, ${ }^{4}$ a single craftsman could be conversant with both artistic formats, as some other works demonstrate. ${ }^{5}$ If the latter is the case, perceived discrepancies in style or quality between the classical and Egyptian components might be attributable to their inherently different demands on the artist.

\section{Provenance}

The Egyptian pictorial field on MFA 54.993 contains three Demotic inscriptions, which are edited below. Because two of the inscriptions (B and C) refer to "Wepwawet of Siut," the provenance of the Boston shroud can securely be ascribed to this town, modern Asyut, which lies on the west bank of the Nile and was the center of the 13th Upper Egyptian nome. As the chief god of Asyut, canine-formed Wepwawet was so closely linked with the town that its Greek name was Lykopolis, the "city of the wolf." For the Ptolemaic Period, Asyut is best attested through an archive of Demotic papyri dating to the reigns of Ptolemy $\mathrm{V}$ and Ptolemy VI (204-145 в.C.), and including a papyrus that refers to special embalming arrangements for the priesthood of Wepwawet of Asyut, ${ }^{6}$ but textual evidence for the Roman Period is minimal.

Tombs in the Asyut necropolis were repeatedly re-used from the Late Period through the Roman Period, ${ }^{7}$ but burials and equipment have rarely been reported from these late stages. Daressy published the inscriptions from an early

\footnotetext{
${ }^{4}$ As in the paintings of the Dakhla Oasis tomb of Petosiris, studied by H. Whitehouse, "Roman in Life, Egyptian in Death: The Painted Tomb of Petosiris in the Dakhleh Oasis," Life on the Fringe: Living in the Southern Egyptian Deserts During the Roman and Early-Byzantine Periods, ed. O. E. Kaper (Leiden, 1998), 253-70; see also J. Osing, Denkmäler der Oase Dachla aus dem Nachlass von Ahmed Fakhry (Mainz, 1982), 81-100, with pls. 25-30; 32-34; 38-39; 41; 42, 1; 43-44; 63b; 71.

${ }^{5}$ E.g. the classical "Victory" figure among the Egyptian deities on the base of the second-century Theban coffin of Cleopatra (British Museum EA 6706: F. R. Herbin, Padiimenipet fils de Sôter. Histoire d'une famille dans l'Égypte romaine (Paris, 2002), 13 fig. 12) and a classical figure of the deceased accompanied by Anubis on a coffin or bier in Berlin (Ägyptisches Museum 12442: illustrated in G. Grimm, Der römischen Mumienmasken aus Ägypten (Wiesbaden, 1974), pl. 137, 2).

${ }^{6}$ H. Thompson, A Family Archive from Siut (Oxford, 1934); A. F. Shore and H. S. Smith, "A Demotic Embalmers' Agreement," Acta Orientalia 25 (1960), 277-94.

${ }^{7}$ PM IV, 265.
} 
Ptolemaic Period, anthropoid limestone sarcophagus found in the town's Muslim cemetery, ${ }^{8}$ and von Bissing and his wife examined the remains of a Roman tomb painting that showed the feet of two figures wearing sandals and standing in a classical, contrapposto posture. ${ }^{9}$ A cedar panel painted with a female portrait and inscribed in Greek for "Tekosis, daughter of Harsunis, 11 years old," was said to be from the vicinity of Asyut when it was purchased in 1909, offering a tenuous link to the site and its environs. ${ }^{10}$ At the foot of the cliffs just west of Asyut, Deir Durunka has also yielded some Ptolemaic, Roman, and early Byzantine funerary remains. ${ }^{11}$ There, in December 1915, Ahmed Kamal discovered two shrouded mummies, one of which bore a Demotic inscription; the mummified remains of an infant and a dog were found alongside them. ${ }^{12}$ Kamal also found both stone and wooden coffins, which he ascribed to the Graeco-Roman Period, along with pottery, a gilded mummy mask ornamented with red flowers and black curls of hair, and a Roman mummy adorned with bracelets, a collar, and sandals, with a garland placed at its head. ${ }^{13}$ The present location of Kamal's finds is unknown.

With the provenance of the Boston shroud established on the evidence of its inscriptions, the shroud is an important addition to the small body of Ptolemaic and Roman funerary material attested from Asyut.

\section{Condition and Assembly}

When the shroud arrived at the Museum of Fine Arts, it consisted of several wrinkled fragments of textile mounted on cardboard. Museum conservators cleaned and assembled at least four distinct pieces of painted linen into a coherent approximation of the intact shroud. In the original Museum mounting of MFA 54.993 (seen in fig. 1), the textile fragments were positioned to minimize any gaps, while the present, more accurate mounting (fig. 2; compare also fig. 3) has separated the portrait head of Fragment 1 from the deceased's arms at the top of Fragment 3, loosely aligning the white painted drapery of Fragment 2 in between. The bottom of Fragment 3 and the top of Fragment 4 share a painted border and thus certainly fit together as mounted, although a tear splits the textile at that point.

MFA 54.993 has sustained damage all around its edges and bears numerous surface cracks in the paint and its gesso ground. In its original disposition as the outer wrapping of an embalmed corpse, the shroud was in all likelihood longer and wider than its preserved dimensions of $1.905 \mathrm{~cm}$ (as assembled) and $47.0 \mathrm{~cm}$, respectively. Dark stains around the perimeter probably result from an oily substance used during embalming or as a libation, and portions of the textile which might have covered the sides and back of the corpse have been trimmed away, leaving a painted area that approximates the surface of a human body. Painted borders at the top of Fragment 1, the sides of Fragment 3, and all around Fragment 4 suggest that a thick red band delineated the entire figured area of the shroud, although it is possible that lost portions of textile also included some decoration.

Throughout, the shroud has suffered paint loss along the smoothed-out lines where it was once creased or folded. Small tears in the textile have been repaired in several places, such as the upper

\footnotetext{
${ }^{8}$ G. Daressy, “Sarcophage ptolémaïque d'Assiout," ASAE 17 (1917), 95-96.

${ }^{9}$ F. W. von Bissing, "Altchristliche Wandmalereien," Festschrift zum sechzigsten Geburtstag von Paul Clemen, 31 Oktober 1926, ed. W. Worringer, H. Reiners and L. Seligmann (Dusseldorf, 1926), 181-88, at 187, with a sketch by the author's wife.

${ }^{10}$ D. L. Thompson, "A Priestess of Isis at Swarthmore College," AJA 85 (1981), 88-92; B. Borg, Mumienporträts. Chronologie und kultureller Kontext (Mainz, 1996), 113, 211 (cat. 15); Ancient Faces (New York), 121-23 (no. 78).

11 PM IV, 269; A. Bey Kamal, "Fouilles à Deir Dronka et à Assiout (1913-1914)," ASAE 16 (1916), 65-114.

12 A. Bey Kamal, "Fouilles à Deir Dronka et à Assiout," 67 nos. 7 and 8.

${ }^{13}$ A. Bey Kamal, "Fouilles à Deir Dronka et à Assiout," esp. 97 no. 115 (Roman amphoras), 111 no. 149 (mummy mask), 113 nos. 159 (mummy) and 160 (mummy case).
} 
bodies of Isis and Nephthys and the solar disk and inscription band above the face of Horus, all in Fragment 3. In Fragment 4, holes in the textile appear near the figure of the libation-pouring goddess and in both feet of the deceased. The portrait of the deceased in Fragment 1 is also riddled by holes in the textile, which are especially apparent in an earlier photograph of the shroud (fig. 1). In the present mounting (fig. 2), small remnants of textile have been positioned more accurately within Fragment 1, and in-painting by conservators has filled gaps in the hairstyle of the subject, in particular the upper, viewer's left area of her head. ${ }^{14}$

The spatial relationship between Fragments 1, 2, and 3 is made problematic by the fact that none of the preserved textile edges join. An earlier attempt to align all three fragments (fig. 1) overlooked the pattern of drapery folds on each piece and merged the hands and neck of the deceased. The revised mounting (fig. 2) improves on this arrangement by separating the three fragments from each other and leaving a gap of at least $10.0 \mathrm{~cm}$ between the bottom of Fragment 1 and the top of Fragment 3. An even larger gap between these fragments should be imagined, however, since the original composition of the portrait would have incorporated both hands of the deceased and at least one hand-held attribute, such as a floral garland. Fragment 2, a rectangle of textile approximately $12.0 \mathrm{~cm}$ by $8.0 \mathrm{~cm}$, depicts curving folds of drapery whose slanting edge crosses one corner. Turned $90^{\circ}$ to the viewer's left from its present position in fig. 2, Fragment 2 seems likely to belong to right shoulder or upper arm of the deceased, where her mantle is gathered to her chest. An alternative position over her left shoulder may also be feasible.

Like the woman depicted on a first-century shroud from Hawara, ${ }^{15}$ the subject of MFA 54.993 holds her hands in front of her chest, and her forearms rise at an angle from her elbows. On either shroud, the woman's right hand rests just above, and barely touching, her left. Most of the right hand has been lost on the MFA example, but it was probably curved around an attribute, in all likelihood a floral garland consisting of pink flowers strung on a cord and doubled into a loop, as on the Hawara portrait shroud. Such garlands also appear on first-century mummy masks from Hawara, usually held in the right hand, occasionally the left. ${ }^{16}$ The garlands have a general association with religious festivities and proliferate in Roman Period funerary art as well as on terracotta figurines of the Ptolemaic and Roman Periods.

\section{The Portrait and its Hairstyle}

The subject of the portrait on MFA 54.993 is a youthful, adult female wearing neatly dressed hair, jewelry of gold and semi-precious stones, and a white mantle draped around her shoulders and held to her chest by her elevated hands forearms. No trace of her tunic is preserved. The enveloping white mantle is unusual because of its voluminous drapes and its color. On mummy portraits, most women wear tunics and mantles in shades of red, pink, blue, or purple, although white mantels are attested from the mid-second century. ${ }^{17}$

The area around the subject's face and body is a creamy color derived from the application of a painted ground or gesso to the linen. The painting is of high quality, with particular attention given to delineating, shading, and coloring the facial features. Red-brown paint applied in strokes of varying thickness is used to outline the face, the fingers, and the fingernails. Yellow-brown paint outlines the arms and details the drapery of the mantle, while short, dark brown strokes are used throughout

\footnotetext{
${ }^{14}$ The repair and in-painting create a misleading impression that there is a vertical, colored band behind the subject's head which joins to the horizontal red border (see fig. 2).

${ }^{15}$ British Museum EA 74709 (formerly National Gallery 1266): S. Walker and M. Bierbrier, Ancient Faces. Mummy Portraits from Roman Egypt (London, 1997), 41-42 (no. 15) [hereafter Ancient Faces (London)].

${ }^{16}$ E.g. Ancient Faces (London), 80-82 (nos. 57-59).

${ }_{17}$ Borg, Mumienporträts, 161, and cf. pls. 11, 1; 17, 1; 35; 44, 2; and 46, 2.
} 


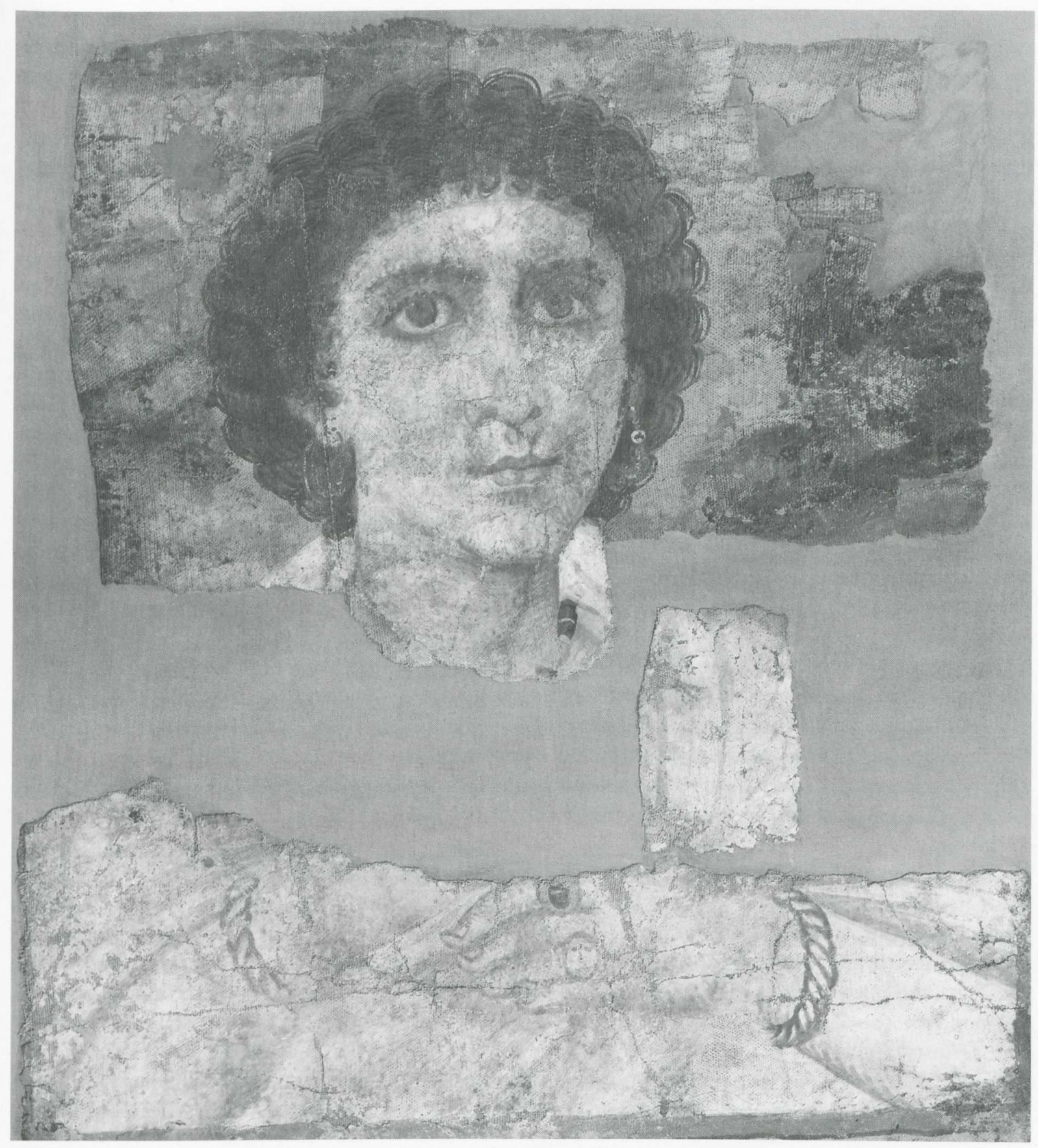

Figure 2. Detail of the portrait of Ta-sheret-Hor-udja, after conservation treatment and remounting in the 1980s. Boston, Museum of Fine Arts MFA 54.993.

the portrait to create shadows and suggest depth, for instance on the undersides of the woman's left arm, chin, and lower lip.

The deceased woman's pale skin is distinguished from the white of her mantle by its pinker tones, as opposed to the more yellow cast of the latter. She has a long nose and prominent chin with wide, slightly oversized and up-turned eyes. The irises are brown and gaze upward, revealing the white of 
the eye below the iris. Dark brown, crenellated lines represent the lashes of each upper eyelid and the sweep of the low eyebrows, while deeper hues of the skin color rim the eyes and shade the curve of the eyeball. Although some paint has been lost from the bridge of the nose, its tip and nostrils and the philtrum of the upper lip are well defined. The lips of the subject's small mouth are painted red and separated by a thin dark line that curves up at the mouth's corners. The darker red color of the upper lip is repeated in the center of the lower lip, giving the mouth a gently pursed or "bee-stung" appearance.

The earrings worn by the deceased consist of a gold hoop, on the front arc of which small beads have been strung; traces of yellow paint remain on the beads. This was a popular and long-lasting type of earring, judging by its appearance on mummy portraits ranging from the early first to the late second centuries A.D., if not beyond. ${ }^{18}$ The pair of bracelets on the subject's wrists are painted white and outlined in a green-tinged blue. Their twisted shape most closely resembles the bracelets on a female mummy mask that probably dates to the late first or early second century A.D.; no portraits with datable Roman hairstyles depict similar bracelets. ${ }^{19}$ The preserved portion of a necklace on the shroud shows that it consisted of oblong beads that taper at either end, alternating in green and black and separated by small, round gold spacers; the black beads are bisected by a thin gold line. Again, the closest parallel for such a necklace is found on female mummy masks of the late first century A.D., although on the masks, the necklaces extend to the subject's chest, whereas the necklace on MFA 54.993 seems to rest at the base of the subject's throat. ${ }^{20}$ The Boston shroud also depicts two rings worn on the preserved left hand of the deceased. On her fourth finger is a gold ring with an incised or raised design indicated on the bevel, and on her second finger is a gold ring set with a black oval stone.

The color of the deceased woman's hair is dark brown; multiple black lines mark both its outline and its internal details. The hair is symmetrically arranged in a circular shape around the head and is divided into evenly spaced segments of waves that radiate from front to back; there is no parting. Small, wispy curls ("snail" curls) border the hairline along the forehead and sides of the face, and the hairstyle exposes the lower third of the subject's ear. Although the rise of the mantle behind the subject's neck somewhat obscures the bottom portion of her hair, it appears that the styled curls ended at the nape.

Comparison with Roman imperial hairstyles provides a vital point of reference for dating portraits from Roman Egypt, since the styles changed regularly and were replicated in portrait paintings and sculpture throughout the Empire. ${ }^{21}$ The hairstyle of MFA 54.993 is problematic, however, for its resemblance to any imperial model is open to debate. When the shroud was first acquired by the Museum, the published opinion of the curators (W. S. Smith of the Egyptian department and C. C. Vermeule of the Classical department) was that the portrait resembled Claudian styles of the early first century A.D.: "The bold expressive modelling of the face is like that of the figures in the Boscoreale frescoes in New York and the mummy portraits, also painted on linen, of the lady Aline and

\footnotetext{
${ }^{18}$ Compare the Demotic-inscribed portrait of Eirene (Stuttgart, Würtembergisches Landesmuseum 7.2), with a JulioClaudian hairstyle, and an anonymous female portrait of late Antonine date (British Museum EA 65343), Borg, Mumienporträts, 30-31, pl. 1,2 and 57-58, pl. 42,2, respectively.

19 The mask is British Museum EA 29476, for which see Ancient Faces (London), 136-38 (no. 143). The date is based on the form of the beaded hoop earrings as well as a general comparison with the style and construction of masks from the vicinity of Meir, e.g., Metropolitan Museum of Art 19.2.6, in Ancient Faces (New York), 129-31 (no. 84).

${ }^{20}$ Compare the necklace added in plaster and semi-precious stone to the Metropolitan Museum mummy mask, detailed in the preceding note.

${ }^{21}$ The most recent and reliable application of this dating technique to Egyptian mummy portraits is Borg, Mumienporträts.
} 
her two children in Berlin." ${ }^{22}$ In his fundamental 1966 study, Parlasca argued that the hairstyle must be Severan in date because the curls swell out from the head rather than lying flat against it. Based on the mistaken reading of "year 11," instead of the correct "year 4," in Demotic Inscriptions A and C (discussed below), Parlasca attributed the woman's burial to the reign of Septimius Severus, the only Severan emperor with a reign of this length; thus the shroud was dated to A.D. $202 / 3 .{ }^{23}$ At the same time, Parlasca commented that the style and quality of the portrait recalled earlier work. ${ }^{24}$ Another alternative interprets the portrait as an Antonine style from the late second century and suggests that the burial was delayed until year 11 of Septimius Severus, as the Demotic text was presumed to attest. ${ }^{25}$ Once the reading of the inscription was clarified as "year 4," rather than 11, the length of Septimius Severus' rule was no longer a valid argument for dating the shroud to this reign; nevertheless, in a subsequent publication Parlasca kept the reign but switched the years, dating the shroud to year 4 of Septimius Severus, or A.D. 195/6. ${ }^{26}$

The difficulties presented by the Boston shroud's hairstyle can be appreciated by considering not only the characteristics of the hairstyle, but also the features that it lacks. Atypically for Julio-Claudian hairstyles, the shroud has no central parting and no curls of hair alongside the neck. ${ }^{27}$ The hair also shows no indication of having been drawn into a bun at the nape of the neck, another feature of Julio-Claudian portraits, nor has it been gathered at the nape of the neck and pulled upward into a braid or bun on the crown of the head, which was usual for both Antonine and Severan styles. Determining the arrangement of the hair at the back of the head is not a straightforward task when the portrait is two-dimensional. It may be that the hidden bottom edge of hair on MFA 54.993 should be interpreted as the beginning of a bun or upsweep, as Borg has suggested for two Severan portrait panels in Munich and the Louvre. ${ }^{28}$ Both of these panels depict women with abundant, halo-like curls around the head, creating an effect that is somewhat similar to the Boston shroud, but there are differences as well: the hair of the Munich and Louvre portraits is disordered in contrast to the rigid and regular swells of the Boston portrait's hair, and the Munich and Louvre portraits have tighter curls at the forehead and wisps of hair in front of the ears, rather than the equal-sized snail curls that lie all along the hairline of the Boston shroud.

A closer parallel to the shroud's hairstyle comes from the panel portrait of Tekosis, daughter of Harsunis, which is also reportedly from Asyut. ${ }^{29}$ Both subjects have regular curls of hair around the face with tendrils at the hairline. However, Tekosis wears dark, reddish-purple clothing and heavy jewelry, and this, together with the style of painting, helps date her portrait to the early Severan era, about A.D. 180-200. As one editor has observed, the "radiating curls of hair" on Tekosis's portrait could, by themselves, suggest an Antonine date in the early second century. ${ }^{30}$

${ }^{22}$ Smith, Ancient Egypt as Represented in the Museum of Fine Arts, 188. The mummy portraits Smith refers to are a group from Hawara to whom a family relationship, and the name of the mother, has been erroneously attributed: see R. Germer, H. Kischkewitz and M. Lüning, "Das Grab der Aline und die Untersuchung der darin gefundenen Kindermumien," Antike Welt 24 (1993), 186-96, and discussion in Parlasca, Mumienporträts, 94-98; L. Corcoran, Portrait Mummies from Roman Egypt (Chicago 1995), 14.

${ }^{23}$ Parlasca, Mumienporträts, 186-87. This is also the date attributed to the shroud in Parlasca, Ritratti di Mummie, 66 (no. 392).

${ }^{24}$ Parlasca, Mumienporträts, 187.

${ }^{25}$ Corcoran in D'Auria, Lacovara and Roehrig, Mummies and Magic, 205.

${ }^{26}$ Parlasca and Seemann, Augenblicke, 228, with the corrected reading credited to K.-Th. Zauzich.

${ }^{27}$ Contrast the portrait of Eirene (n. 18) and a portrait in Hannover (Kestner-Museum 1966.89, in Borg, Mumienporträts, 29-30, pl. 1,1).

${ }^{28}$ Munich, Staatliche Sammlung Ägyptischer Kunst 1, and Louvre P 211: Borg, Mumienporträts, 65-66, pls. 38 and 44,2.

${ }^{29}$ See n. 10.

${ }^{30}$ Ancient Faces (New York), 123. 
The portrait on MFA 54.993 thus has four key features: 1) its pose, with the right hand probably holding a floral wreath; 2) the white mantle, which is a second-century trend on mummy portraits but is depicted on this shroud in a more full and freely draped manner than elsewhere; 3) earrings, a necklace, and bracelets with parallels ranging from the late first to the late second centuries A.D.; and 4) a hairstyle that has been variously assigned to the early first century, the second century, or the late second to early third century A.D. How these features relate to the date and context of this object will be considered in the conclusion, alongside the evidence of the shroud's inscriptions.

\section{The Egyptian Registers}

Two registers of Egyptian scenes comprise the shroud's largest painted area (see fig. 1), which is framed on each of its four sides by a continuous red border. A yellow background unifies both registers, and the colors pink, blue, white, and black dominate the decoration. Despite a difference in height between the two registers, they employ the same scale for human figures. The upper register is fully preserved to the width of the shroud (approximately $47.0 \mathrm{~cm}$ ) and is taller than it is wide, whereas the lower register is shorter than it is wide. The sides of the lower register taper inward at the bottom, and its bottom corners have sustained damage, in particular the viewer's left-hand side.

At the top of the upper register, a winged scarab fills the added height above the figures of Isis, Osiris, and Nephthys. The scarab grasps two disks, one each between its front and rear legs. Balanced atop each of its outspread wings is an ankh sign drawn in three distinct parts (foot, crossbar, and a disk-like, rather than teardrop-shaped, loop). The body of the scarab is black, its innermost wing feathers blue, and its outermost wing feathers pink. In funerary art, the winged scarab is a multivalent symbol and frequently appears over or on top of the head of the deceased, or on the chest, like a pectoral. It is associated both the rebirth of the sun disk in the morning and with the rejuvenation of Osiris, from under whose head a winged scarab emerged. ${ }^{31}$ The imagery of the upper register thus evokes the twin solar and Osirian aspects of rebirth.

Directly beneath the scarab, Osiris stands in profile, facing the viewer's left. He is flanked by Isis and Nephthys, each of whom pours a libation from a hes-vase onto an offering table. All three figures stand on a yellowish-brown ground line. Positioned under the scarab's wings and between the headdresses of Isis, Osiris, and Nephthys are two inscription columns left blank. The columns are bordered in black and filled in with pink, and their position might relate either to the scarab or to Osiris and the goddesses. Although anepigraphic, the columns were presumably considered integral to the scene, whether to reinforce its traditional Egyptian appearance, fill space, or adhere to a model. In contrast, the Demotic texts in this register were positioned where the background offered free space, with little or no reference to the pictorial decoration: Inscription A is above the feet of Osiris, Inscription $\mathrm{C}$ is behind Nephthys and is arranged horizontally in relation to the corpse, not the figures.

Osiris has blue-green skin, a large eye, and a divine beard that curves steeply away from his chin. He wears a blue atef-crown with a pink, papyriform top and feathered sides that are not connected to the central portion of the crown. The body of Osiris is shrouded from neck to ankle, his feet are bare, and his wrists and clenched hands emerge from the front of the profile torso, the right hand above the left. His fists grasp an ankh sign adjoined by two flails, a variation of the crook and flail or crook, flail, and was-sign iconography that is more typical for Osiris. Around his upper chest is a broad collar drawn with black vertical lines and alternating horizontal bands of blue, pink, and white. Just below the bottom border of the collar is a black chevron from which a series of short, diagonal lines ema-

${ }^{31}$ M. A. Stadler, "Der Skarabäus als Osirianisches Symbol vornehmlich nach spätzeitlichen Quellen," ZÄS 128 (2001), $71-83$. 
nates and runs down the center of the god's body. These dashed lines and the chevron are a common device on two-dimensional representations of mummiform figures in the Ptolemaic and Roman Periods and were perhaps intended to suggest the figures' depth or roundness. ${ }^{32}$ Projecting from the front of Osiris's lower body are loop-like frills painted in blue, pink, and white stripes. These frills seem to refer to the piece of cloth sometimes shown knotted around a deity and recur in this guise, without the knot or cloth itself depicted. ${ }^{33}$

The figures of Isis and Nephthys are nearly identical. Like Osiris, the goddesses have blue-green skin and bare feet. Isis, who stands to the viewer's left in front of Osiris, wears a transparent sheath from below her breasts to the top of her ankles; the lines of her thighs, rounded abdomen, and navel are visible through the garment. The goddess is identified by her name hieroglyph, which is painted pink and blue and rests on a plinth-like support on top of her head. A narrow collar striped in white and blue encircles her neck. Her tripartite hair or wig is black with no inner detailing, and she wears a pink fillet around her forehead, with no ties indicated. Nephthys is identified by her own name hieroglyph, and her figure differs from that of Isis in only a few details. The top of Nephthys's sheath dress is defined by a horizontal band, and a white strap extends from the top of the dress over her right shoulder. Her collar is pink, and her own pink fillet has twin ties that trail down the back of her hair.

Each goddess holds a pink hes-vase in her near hand (the left hand for Nephthys, right for Isis) while raising the other hand towards Osiris in a gesture of adoration or protection. Two blue zigzags of water flow from the hes-vase to the top of the offering table that separates each goddess from Osiris. The offering tables consist of a blue lotiform stand supporting a three-sided, rectilinear altar, on top of which rest three circular loaves and an upright lotus. The goddesses and their libations serve to protect, revivify, and sustain both Osiris and the deceased.

The lower register is bordered at the top by a pink band and at the bottom by a red ground line. Four anepigraphic inscription columns abut the top border and preserve traces of pink within their black outlines. This register depicts a unique variant of the sema-tawy motif representing the cosmic union of two entities, specifically Upper and Lower Egypt. Horus and Anubis tie together the lotus and papyrus plants that embody, respectively, the southern and northern parts of Egypt. The gods stand amid stalks of papyrus painted white, pink, and blue, and a large, central lotus flower blooms level with their shoulders. On top of the lotus is a supine mummiform figure, its head to the viewer's left. Above the mummy is Demotic Inscription B, which repeats the name of the deceased from Inscription $\mathrm{C}$ and thus identifies this figure with the dead woman.

The falcon-headed Horus appears at the viewer's left in the scene, bracing his body with his advanced leg as he pulls on a long, twined stem that terminates in a lotus blossom. Horus wears a blue, pink, and white collar and a pink, striped tripartite wig with the far lappet also depicted; he has blue flesh and bare feet. His kilt and corselet are striated with black lines and striped in painted bands of blue, pink, and white. A pink strap descends from his left shoulder to the top of his corselet. His hands are differentiated, with the knuckles and clenched fingers of his left hand depicted where he grasps the plant. Horus has a solar disk on top of his head, drawn with a double outline and colored pink. By the Roman Period, the addition of a disk could emphasize the solar aspect of many deities in funerary roles.

\footnotetext{
32 Thus, a chevron and dashed lines are drawn on the splayed breasts of the goddess Nut inside the coffin lid of Heter, according to the copy made by H. Brugsch: O. Neugebauer and R. A. Parker, Egyptian Astronomical Texts III. Decans, Planets, Constellations and Zodiacs (Providence, 1969), pl. 50.

${ }^{33}$ See Kurth, Der Sarg der Teüris, 46-47.
} 
To the viewer's right, the figure of Anubis mirrors that of Horus. Due to the difference in height between Anubis's jackal head and Horus's falcon head, the artist has elongated the torso of Anubis and deepened his blue, pink, and white-banded collar. Anubis has black flesh and a blue tripartite wig with both lappets visible. His corselet and the front section of his kilt are white, while the rear of his kilt is striped blue, pink, and white, like Horus's kilt. A pink strap passes over his right shoulder, and the looped stem that he grasps has a papyrus blossom at its end.

The papyrus umbels and large lotus in between the gods continue the blue, pink, and white color scheme. On top of the lotus, the supine mummy has a pink shrouded body, green face, and blue tripartite wig. Narrow horizontal stripes between the back and front lappet of the wig probably represent the bands of a broad collar, and a chevron and dashes on the side of the body replicate the markings on Osiris in the upper register. A narrow blue band at ankle level suggests a break between the mummy's shrouded body and the high projection of its wrapped feet. ${ }^{34}$ Written in the confined space above the mummy and between two of the uninscribed columns, Inscription B makes explicit the connection between this mummy and the deceased, so that the "action" and efficacy of the scene applies to her.

The form of the sema-tawy motif in this register is exceptional, as is its use in a funerary context. The scene is more typical of temple and throne decoration, where the binding together of the plants is performed either by fecundity figures or by pairs of deities, usually Horus and Seth or Horus and Thoth. ${ }^{35}$ One scene in the first hypostyle hall of the temple of Sety I at Abydos shows Horus performing the sema-tawy with Wepwawet, perhaps because of the latter's local cult. ${ }^{36}$ In royal iconography, the sema-tawy was closely associated with thrones and coronation, and it could also appear on the sides of bark stands, or to support offerings or deities in temple reliefs. ${ }^{37}$ On MFA 54.993, the sema-tawy supporting the mummy recalls the use of the sema-tawy beneath kings and gods, since the rejuvenated dead acquired kingly and divine qualities. Specifically, the blooming lotus flower and the mummy mirror the symbolism of the sun-god being reborn from a lotus in the morning. ${ }^{38}$ In funerary art and papyrus vignettes, the lotus blossom often supports the Four Sons of Horus, probably because of a solar association as well. ${ }^{39}$ The pairing of Horus and Anubis for the Boston shroud's sema-tawy, rather than Horus and Thoth, no doubt reflects the important role of Anubis as an embalmer and as the "psychopomp" who led the deceased to the afterlife and presented them to Osiris. Given the Asyut provenance of the shroud, the link between Anubis and Wepwawet, because of their canine forms, might also have influenced the rare iconography of this scene.

\section{The Foot Projection}

Because the foot area of MFA 54.993 would have sloped upwards with the feet of the corpse when originally in place, the flat mounting of the shroud leaves the painted feet and surrounding decoration upside-down in relation to the viewer. Turned "upright," the composition of the foot projection is clear: on either side of the slender ankles and sandal-clad feet of the deceased is a lotiform col-

\footnotetext{
${ }^{34}$ For which compare the high foot projections of actual mummies, n. 3 above.

35 J. Baines, Fecundity Figures (1985, reprint ed. Oxford, 2001), 134-39, 226-76.

${ }^{36}$ Baines, Fecundity Figures, 262. The scene, from the reign of Ramesses II, is unpublished, but see PM VI, 5 (45).

37 Coronation: Baines, Fecundity Figures, 261-65, 229, fig. 128 and 270-71, for a Hibis temple scene with a sema-tawy supporting the enthroned king; on bark stands (137, 253 fig. 147); supporting offerings (236-38); and supporting deities (138).

${ }^{38}$ Baines, Fecundity Figures, 275 compares the Boston shroud sema-tawy to a bronze statuette base (272 fig. 163) that depicts fecundity figures flanking the lotus and child sun-god.

${ }^{39}$ E.g. on a funerary bier in Berlin (Ägyptisches Museum 12442), illustrated in Kurth, Der Sarg der Teüris, 41, fig. 5, and on papyri such as J. Quaegebeur, "Books of Thoth Belonging to Owners of Portraits? On Dating Late Hieratic Funerary Papyri," Portraits and Masks, ed. M. L. Bierbrier (London, 1997), 72-77, examples on pl. 35.
} 
umn supporting a $b a$-bird who receives libations from the goddess who stands between the feet, also on a lotus. The soft coloring of the feet is in keeping with the paint effects used in the woman's portrait, as opposed to the bold outlines and bright colors of the Egyptian registers and of the goddess and $b a$-birds here. Pink and brown contours outline the ankles, feet, and toes, and brown hatching on the sandals represents basketry. Like the portrait, the foot projection has a cream-colored, gesso background.

In between the deceased's feet, a tall blue stem supports a blue, pink, and white lotus blossom on which a goddess stands; the top of her head seems to be devoid of insignia, but it is partly obscured by staining. Two pink anepigraphic columns are depicted, one near each upper corner of the foot projection, inside its surrounding red border. The goddess has blue skin and black, tripartite hair. She wears a yellow collar and a pink sheath dress that extends from below her breasts to her ankles. The goddess holds out a green hesvase in each hand from which a jagged blue stream of water flows. A goddess pouring libations to the $b a$ can be associated with the goddess of the sycamore tree, variously identified as Nut, Hathor, Isis, or Amentet in Egyptian evidence. ${ }^{40}$

The $b a$-birds stand on shorter lotiform supports that have three-sided rectilinear tops, like the offering tables of the upper register. The stems of the supports are pink, while the lotus blossoms are variegated blue, pink, and white. Although $b a$-birds can be represented with distinct male or female hairstyles to correlate with the sex of the deceased, the examples here have short hair, which is generally more typical for a male representation but may also suit a female. ${ }^{41}$ Their faces are green and their bodies are feathered blue and pink; each has a solar disk on its head. ${ }^{42}$ Only the $b a$-bird next to the deceased's left foot has a human arm extended to cup the libation in its hand. The motif of a goddess pouring out water to a $b a$-bird, or some other manifestation of the deceased, appears frequently in Roman Period funerary contexts, and,

${ }^{40}$ M.-L. Buhl, "The Goddesses of the Egyptian Tree Cult," JNES 6 (1947), 80-97; I.-G. Wallert, “Baum, heiliger,” LÄ I, 655-60.

${ }^{41}$ For different hairstyles on ba-birds, contrast the cropped hairstyle for a male $b a$-bird on the back of Berlin, Ägyptisches Museum 34435 and the long, curly hairstyle for a female $b a$-bird on the back of Berlin, Ägyptisches Museum 34434: D. Wildung, “Geheimnisvolle Gesichter," Antike Welt 21 (1990), 206-21, figs. 19b and 18b, respectively. On the coffin of Teüris, two $b a$-birds have either short or shoulder-length hair, while a similar coffin depicts $b a$ birds with long, curly hair: Kurth, Der Sarg der Teüris, pls. C,2 and 10,1, respectively. Since both coffins are for women, all three hair lengths seem to be suitable for $b a$-birds of the female deceased.

${ }^{42} \mathrm{Ba}$-birds can also wear the atef-crown: see Kurth, Der Sarg der Teüris, pl.

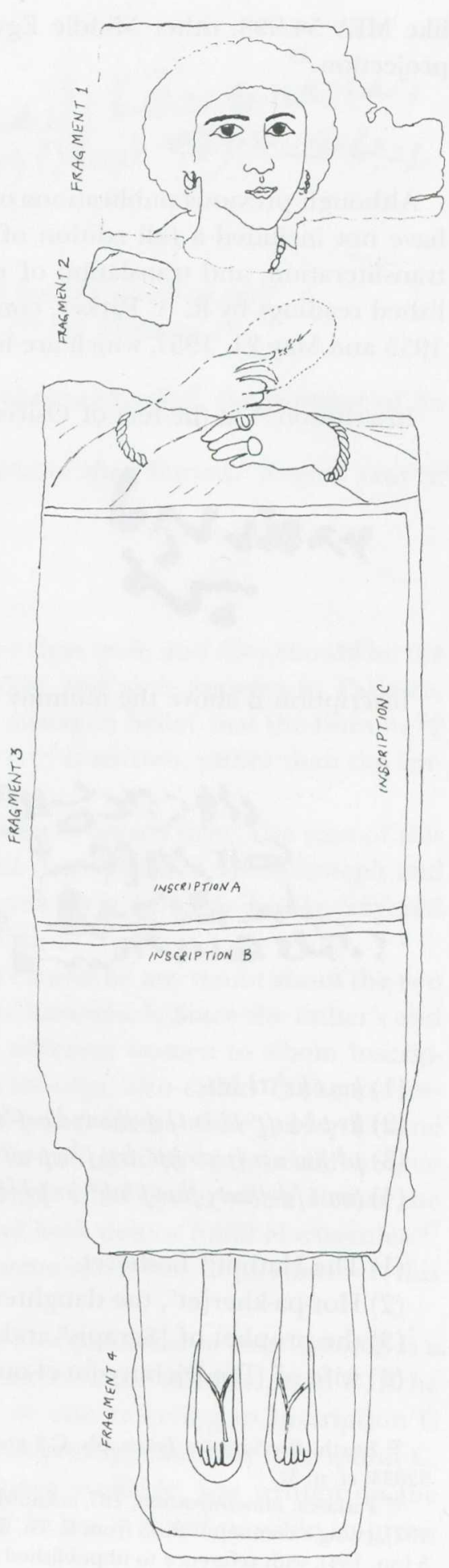

Fig. 3. Suggested reconstruction of the shroud, to accommodate a floral garland in the right hand of the deceased and to reposition Fragment 2. (Authors' drawing) 
like MFA 54.993, other Middle Egyptian coffins and shrouds incorporate the scene into the foot projection. ${ }^{43}$

\section{The Demotic Inscriptions}

Although previous publications of the shroud have suggested readings of the Demotic texts, they have not included a full edition of the three difficult inscriptions. ${ }^{44}$ Presented here is a facsimile, transliteration, and translation of each inscription. The commentary that follows refers to unpublished readings by R. A. Parker, contained in letters he wrote to curator W. S. Smith on February 17, 1955 and May 21, 1957, which are housed in the records of the MFA's Egyptian department. ${ }^{45}$

Inscription A at the feet of Osiris, for whom Isis and Nephthys libate:

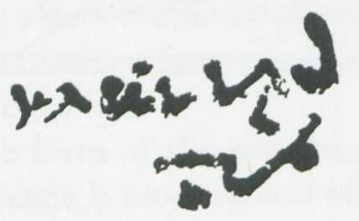

ḩ3.t-sp 4.t a 3 bd 3 šmw sw 14

Regnal year $4^{\mathrm{a}}$, month 3, day 14 .

Inscription B above the mummy lying on top of a lotus:

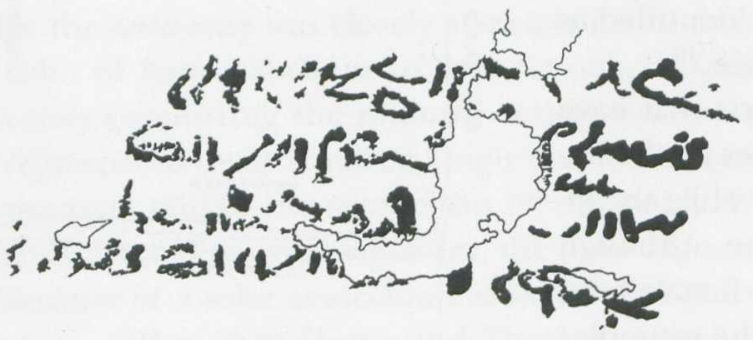

(1) hiw.t-hr. $r^{b} t 3-s ̌ r . t-$

(2) $h r-p 3-\underline{h} r\left[t_{\Lambda}^{c} t 3\right.$ šr.t] $\underline{d}-\underline{d} h \underline{w} w t y-i w=f-{ }^{-} n \underline{h}^{d}$

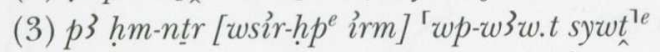

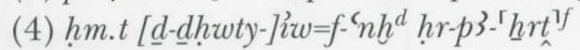

(1) The Hathor ${ }^{b}$ Ta-sheret-

(2) Hor-pa-kher[et ${ }^{\mathrm{c}}$, the daughter of] Dje-Djehuty-iu-ef-onkh ${ }^{\mathrm{d}}$,

(3) the prophet of [Sarapis ${ }^{\mathrm{e}}$ and] ' ${ }^{\mathrm{T}}$ Wepwawet of Siut ${ }^{\mathrm{Te}}$,

(4) wife of [Dje-Djehuty-]iu-ef-onkh ${ }^{\mathrm{d}}$ Hor-pa- ${ }^{\mathrm{r}}$ kheret ${ }^{\mathrm{lf}}$.

${ }^{43}$ Kurth, Der Sarg der Teüris, pls. C,2 and 10,1 (cf. n. 41); Parlasca and Seemann, Augenblicke, 313 no. 206h (now Louvre E 32634; cf. n. 3).

${ }^{44}$ Parlasca, Mumienporträts, 187, acknowledging the opinion of E. Lüddeckens; Parlasca and Seemann, Augenblicke, 228 (no. 137), citing a communication from K.-Th. Zauzich; and Corcoran, in D'Auria, Lacovara and Roehrig, Mummies and Magic, 2045 (no. 154), with reference to unpublished readings by R. A. Parker, reviewed by R. Jasnow.

${ }^{45}$ In his 1957 letter to W. S. Smith, Parker mentions M. Malinine's opinion about the inscription; the two Demotists presumably conferred while Malinine was a visiting professor in Parker's department at Brown University during the 1956-57 academic year. 
Inscription $\mathrm{C}$ behind Nephthys at the proper left margin:

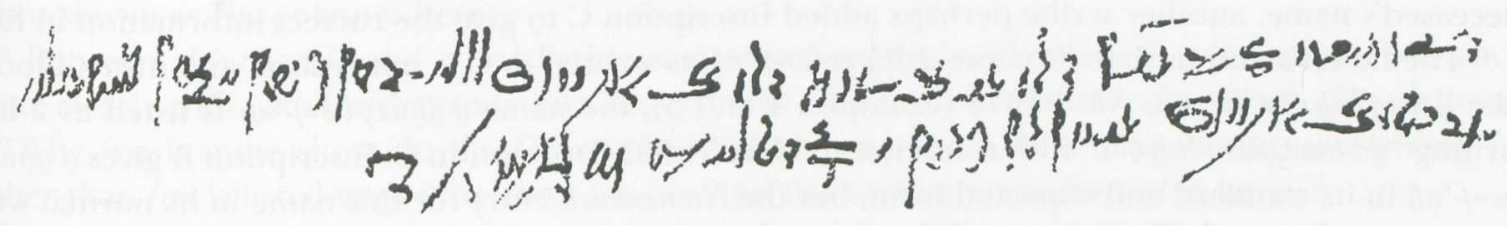

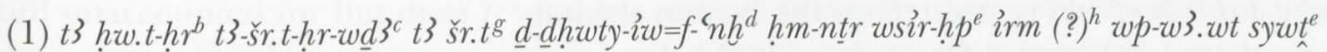

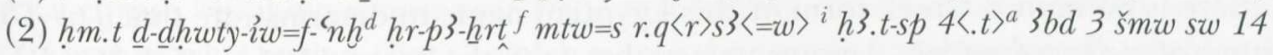

(1) The Hathor ${ }^{b}$ Ta-sheret-Hor-udjac ${ }^{c}$, the daughter ${ }^{\mathrm{g}}$ of Dje-Djehuty-iu-ef-onkh ${ }^{\mathrm{d}}$, the prophet of Sarapis ${ }^{\mathrm{e}}$ and $(?)^{\mathrm{h}}$ Wepwawet of Siut $\mathrm{t}^{\mathrm{e}}$,

(2) wife of Dje-Djehuty-iu-ef-onkh ${ }^{d}$ Hor-pa-kheret $^{f}$. It is she whom they buried. ${ }^{\mathrm{i}}$ Regnal year $4^{\mathrm{a}}$ month 3 of the summer, day 14 .

\section{Commentary}

a The writing of the date is somewhat obscure in C ( $\%$ ), but very clear in A, and they should be the same. The date is certainly not 11 in A, as it was read by Parker and as it appears in Parlasca, Mumienporträts (see $\mathrm{n}$. 23). This erroneous reading is due to the mistaken belief that the lines in $\boldsymbol{\imath}$ are ligatured but not meant to be connected, i.e, that $10 . t$ plus $1(\mid \hat{\imath})$ is written, rather than the correct $4 . t($ ( $)$.

${ }^{\mathrm{b}} h w . t-h r$ is the epithet of a deceased woman just as wsir is used for a deceased man. The root of this gender distinction goes back as far as the Middle Kingdom: In the inscription of Mentuhotep's and Nefermesut's statues (Oxford, Ashmolean Museum E.1971) the woman is im 3h.t hr h. hw.t-hr "revered before Hathor" and the husband is im $3 h$ hr wsi $r$ "revered before Osiris." 46

'Very oddly the woman's name is different in B and C, but there cannot be any doubt about the two readings, even though $t 3-s$ s.t- $h r-p 3-h r t$ is not listed in the Demotisches Namenbuch. Since the father's and husband's names are identical, it is not possible to postulate two different women to whom Inscriptions B and C refer. Thus the woman may be named "Ta-sheret-Hor-udja, also called Ta-sheret-Horpa-kheret." It is tempting to interpret this exchange of two Horus-names in the same person's name theologically: The sound Horus and Horus, the child, are the same in anticipation of the child's rescue from dangers. This may be compared with the theology of the temple of el-Qal'a, where Horus, the child, is divided into two deities through antonomasian diastasis, and both deities fulfill Horus-roles: ${ }^{47}$ the heir of the paternal functions is Horus, the child, and the legitimate son is Hor-udja. However, this is purely a hypothesis and should not be pushed too far.

Alternatively, one could assume that the occurrence of Ta-sheret-Hor-pa-kheret in Inscription B is a scribal error resulting from the scribe's mistaken recollection of the content of Inscription C, if he were, for instance, writing from an oral memory or instruction, or else referring to Inscription C while writing his own text at a 90-degree angle. This last suggestion presupposes that Inscription C, which is in a more even hand and for which there was ample space available, was written on the shroud prior to the more cramped and untidy Inscriptions A and B, but it is not possible to prove

\footnotetext{
${ }^{46}$ W. M. F. Petrie, Dendereh 1898 (London, 1900), pls. 15, 21.

${ }^{47}$ C. Traunecker, "Lessons from the Upper Egyptian temple of el-Qal'a," in The Temple in Ancient Egypt. New Discoveries and Recent Research, ed. S. Quirke (London, 1997), 171-72.
} 
that this was the case. If, instead, Inscriptions A and B were written first and included an error in the deceased's name, another scribe perhaps added Inscription C to give the correct information in full.

d The father's and husband's name $\underline{d}-\underline{d} h w t y-i w=f-{ }^{-} n h$ as written in $\mathrm{C}$ is not typical, and instead looks like $\underline{d}-t w=f-' n h$. In Demot. $N b$. I 1378 (examples 4 and 5), the name $\underline{d}-\underline{d} h w t y$-i $w=f^{-} n h$ is listed as a late writing “d $d$-thwtj-iw=f-' $n h$ (?)," with reference to MFA 54.993, Inscription C. Inscription B gives $d$-dhwty$i w=f^{-} n h$ in its standard and expected form, but the Namenbuch entry for this name in its normal writing (Demot. Nb. I 1376) makes no reference to the Boston shroud, i.e, according to Demot. Nb. only $\underline{d}-t w=f^{-} \cdot n h$ (read $\left.\underline{d}-\underline{d} w h t y-i w=f \cdot{ }^{c} n h\right)$ is attested on the Boston shroud.

Unfortunately, there is no known Greek form of this Egyptian name to demonstrate that $\underline{d}-\mathrm{t} w=f_{-}{ }^{\prime} n h$ is a phonetic writing of $\underline{d}-\underline{d} h w t y-i w=f-n h$. Among names that take the form $\underline{d}$-DN-i $i w=f$-' $n h$ "God NN said: 'He will live,'” only the following have been associated with proposed Greek forms: $\underline{d}-p t h$-i $w=f$ -

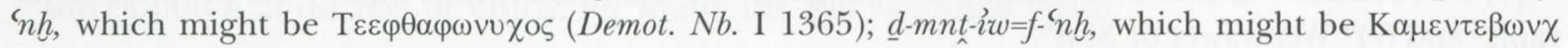
(Demot. $N b$. I 1366, with a problematic K at the beginning); and $\underline{d}$-hnsw-i $w=f$ - $n h$ which might be Xev$\sigma \varepsilon \varphi \omega \vee v \chi \circ \varsigma$ (Demot. Nb. I 1374-75, beginning with X for the Egyptian $\underline{d}$ ). Thus $i w=f$ - $^{\prime} n h$ takes either the


From these Greek comparisons, it might be possible to reconstruct the pronunciation of $\underline{d}-\underline{d} h w t y-i w=f$ ' $n h$ as something like "Te'etotefōnkh," or the more exceptional "Te'etotebōnkh." Since the repeated consonants might have presented difficulty, with their rather stuttering sounds, it may be that "Te'etot-" merged into "Te'ete-" and that this is reflected in the use of $\underline{d}-t w=f-' n h$ (Te'etefōnkh) as a phonetic writing for $\underline{d}$ - $d h w t y-i w=f-n h$.

e An Osiris cult with a hm-ntr "prophet" in Asyut is also attested for the Late Period in P.Cairo 50058, 1 (reign of Amasis) and with a fkt-priest in P.Cairo 50059, 2 (reign of Cambyses); the cult was more or less closely linked with Asyut since the Pyramid Texts. ${ }^{48}$ The reading $w i \hat{r}-h p$, adopted here, was also proposed by Parker. It must be admitted that $h p$ is a doubtful reading, ${ }^{49}$ and it would be preferable to identify it, together with the following group, as a toponym, resulting in the parallel construction "prophet of Osiris of 'site X' and Wepwawet of Siut." However, neither the regional Asyut cult place of Osiris ( 3 -qrr.t) nor the epithet hnt-imnt can be seen in the group under consideration. If the reading wsir- $h p$ is correct, Inscription $\mathrm{C}$ remains the only Egyptian evidence for a cult of OsirisApis or Sarapis in Asyut, although the distinction may be negligible since the Osirian quality and identity of Sarapis persisted in Egypt throughout the Roman Period. ${ }^{50}$ Further, though oblique, evidence for a Sarapis cult in Roman Asyut might be suggested by an Abydos stela inscribed in Greek for the Lykopolite Apollonios (Louvre N 328), dating to the 1st century A.D.: while the stela depicts Osiris, the inscription refers only to Sarapis. ${ }^{51}$

${ }^{\mathrm{f}}$ Following the husband's name we find a second name, which is either a sort of pseudonym or his father's name with an omitted $s 3$ "son of" before it. The divine name of Harpokrates $(h r-p 3-\underline{h} r t)$ is rarely attested as a personal name in Demotic (Demot. Nb. I 805). Thus the woman's father and husband, who bear the same name, are distinguished by the father's title and by the husband's additional, possibly patronymic, name. In Inscription B, line 4, the writing runs up to Horus's beak and the signs after $h r$ are almost completely destroyed. It can be excluded that $h r-p 3-\underline{h} r t$ refers to the Horus-figure

${ }^{48}$ W. Spiegelberg, Die Demotischen Denkmäler III. Demotische Inschriften und Papyri, Catalogue général des antiquités égyptiennes du Musée du Caire (Berlin, 1932), 39-46, pls. 17-20; H. Beinlich, “Assiut,” LÄ I, 489-95, at 492.

49 The writing is not typical (compare Demotisches Glossar, 301-2), but a very similar one, albeit lacking the first tall sign, is found in Ptolemaic Memphis: P. W. Pestman, Recueil de textes démotiques et bilingues I. Transcriptions (Leiden, 1977 ), 5.

${ }^{50}$ Cf. G. Hölbl, “Serapis,” LÄ V, 870-74, at 871.

${ }^{51}$ P. Koemoth, “À propos de la stèle d'Apollônios (Louvre N 328): Ophoïs, Osiris et Sérapis en Abydos,” SAK 29 (2001), 217-33 ; discussed further below, under "Palaeography and Dating Considerations." 
there as a caption, because it also follows $\underline{d}-\underline{d} h w t y-i w=f-{ }^{-} n h$ in Inscription $\mathrm{C}$, line 2 , and because Horus is not shown as Harpokrates here.

g Between $t 3$-šr.t-hr-wd 3 and $t 3$ šr.t Parker saw something he marked by "r. . .", but the woman's name clearly ends with the determinative "seated man with hand to mouth," after which $t 3$ šr.t follows.

${ }^{\mathrm{h}}$ The irm is quite short. In the Demotisches Glossar, however, a Ptolemaic writing resembling i $i w$ rather than irm is listed under the entry for irm, and this writing is similar to irm here. ${ }^{52}$

i Parker interpreted $r q\langle r\rangle s 3$ as $r$ plus infinitive and translated "for burial"; this leaves the preceding word unaccounted for but does resemble common formulae that give instructions or permission to bury a corpse. ${ }^{53}$ Taking $m t w=w r . q\langle r\rangle s\langle\langle s\rangle$ as a relative construction in a cleft-sentence pattern results in "it is they who buried 〈her〉," which solves the former interpretation's problems but generates a few new ones. ${ }^{54}$ First, the participial form should be $i . i r q\langle r\rangle s 3$. To counter this objection, $r . q\langle r\rangle s 3$ could be explained as an archaizing participial form that occurred because $q\langle r\rangle s 3$ had lost one of its three radicals in the course of phonetic change and thus did not require a periphrastic form, like $\underline{d} d$, ir or $h p r$ in Late Egyptian. ${ }^{55}$ A second problem with the interpretation is that it requires emending the resumptive pronoun -s. Finally, this type of cleft-sentence pattern is not attested with a participle elsewhere, but with relative forms or $n t$-conversions.

Another interpretation, used in the translation here, demands fewer emendations but does raise other objections: $m t w=s r . q\langle r\rangle s 3\langle=w\rangle$ "it is she whom $\langle$ they $\rangle$ buried." In this case, the missing $\langle=w\rangle$ can easily be explained as a haplography that occurred because of the tall stroke of the following $h 3 . t-s p$. In a relative form the antecedent that serves as direct object of the relative phrase is not pronominally resumed ${ }^{56}$ Thus an emendation of a dependent pronoun is not required. The only remaining problem is the fact that $m t w=s$ does not look like $m t w=s$, but in that area of the shroud, the damage obstructs a clear reading. Considering the weight of the objections against the various alternatives, it seems sensible to adopt the last option, albeit with the provisos mentioned. With this reading, the sentence does not reflect "practical instructions between funerary priests and cemetery officials," ${ }^{57}$ but merely confirms who is being buried.

\section{Palaeography and Dating Considerations}

Before embarking on a palaeographical study of MFA 54.993, it must be stated that two different hands are attested on the shroud: one hand wrote Inscriptions A and B, while another, more careful hand wrote Inscription C. In neither hand does the writing of the signs show any peculiarities that might help date the shroud, with one exception: the theonym of Asyut's main deity, Wepwawet, which is written quite differently in Thebes, for example, ${ }^{58}$ and thus offers itself as a starting-point for investigation.

To permit a proper palaeographical dating, however, the sources must fulfill certain conditions. Foremost is the need to have a series of well-dated writings from Asyut, from all phases of the Demotic script, in order to show whether there was a diachronic change in how Asyut scribes wrote the

\footnotetext{
52 Demotisches Glossar, 39.

${ }^{53}$ As on mummy labels, where the formula resembles a command more than a permission to bury: riry $q\langle r\rangle$ s.t "Perform burial!," in A. e-H. Nur el-Din, E. Boswinkel and P. W. Pestman, Textes grecs, démotiques et bilingues (P. L. Bat. 19) (Leiden, 1978), 171-89.

${ }^{54}$ For this construction in Demotic, see most recently R. S. Simpson, Demotic Grammar in the Ptolemaic Sacerdotal Decrees (Oxford, 1996), 168.

${ }^{55}$ F. Junge, Einführung in die Grammatik des Neuägyptischen (Wiesbaden, 1996), 68.

${ }^{56}$ W. Spiegelberg, Demotische Grammatik, Heidelberg: Winter (1925), § 549.

57 D'Auria, Lacovara and Roehrig, Mummies and Magic, 205.

${ }^{58}$ Compare p3-ti-wp-w3.wt as written in P. BN 218: Demot. Nb. I 297, no. 12.
} 
god's name. Furthermore, if the provenance of the shroud were in question-which, thanks to the content of the inscriptions, it is not-attestations of the god's name from other places in Egypt would help to make apparent the local idiosyncrasies of Asyut.

Not surprisingly, "Wepwawet" principally occurs in the personal names of people from Asyut: $w p$ w3.wt-iw (Demot. Nb. I 115), wp-w3.wt-i.ir-ti-s (Demot. Nb. I 115), wp-w3.wt-rs (Demot. Nb. I 116), wp-w3.wthtp (Demot. Nb. I 116), p3-ti-wp-w3.wt (Demot. Nb. I 297; 526-27), ${ }^{59}$ and $\underline{d} d$-wp-w3.wt-[i $\left.i w=f-\right]^{4} n h$ (Demot. $N b$. I 1363). The writing of $w p$-w3.wt does not change according to where it appears; that is, all other factors being equal, it is written in a personal name just as it would be in an expression like pr $n w p$ w3.wt. A palaeography of the god's name Wepwawet-[ 2 is the writing on the shroud-can be reconstructed from onomastic evidence, and Table 1 is comprehensive insofar as it lists writings of the god's name for all locations and periods where and when it has been attested. ${ }^{60}$ For Asyut, a representative selection of Early and Middle Demotic names has been chosen; there are no Late Demotic examples from the site.

The table demonstrates that (a) there is an Asyut form of $w p$-w3.wt which is distinct from those writings found in other Egyptian sites, and (b) there is hardly any evidence for Late Demotic writings of wp-ws.wt and none from Roman Asyut. In light of the conditions set out above, one must conclude that the sources are not sufficient for determining the date of the handwriting on the shroud by palaeographic means focused on the divine name, because Asyut does not supply us with a chronological series of $w p$-w3.wt writings from Early to Late Demotic. Thus we cannot say how the writing of the theonym developed there in Roman times. Admittedly, at first sight the Middle Demotic attestations closely resemble the writings of $w p$-w3.wt on the Boston shroud, which would point to an early 2nd century B.c. date since all of the Middle Demotic writings in the table come from the Asyut family archive (c. 170 B.C.) ${ }^{61}$ However, at almost the same time or shortly after (146 B.C.), scribes in Thebes wrote $w p-w 3 . w t$ quite differently. Therefore the form [ $[2$ for $w p-w 3 . w t$ confirms the shroud's Asyut provenance, but it does not suggest its date.

A few other palaeographic observations can be made, but all meet the same difficulties of finding diachronic comparanda from Asyut. For instance, 5 ' $n$ h in the shroud's Inscription C looks like 6 in ' $n$ h in a Theban Book of the Dead dated to A.D. 63 (P. BN 149 I 1 and 8), ${ }^{62}$ with the two quite straight strokes for '; however, this might be a scribal idiosyncrasy, since the scribe of the 3rd-century в.c. Legal Manual of Hermopolis used the same sort of ', for example. ${ }^{63}$ Still, the writing of ' $n h$ might tentatively be taken as an anchor for dating, and the very even thickness of its strokes suggests that the scribe used a reed (calamus) rather than a rush. This would render a Ptolemaic date for the shroud implausible and might agree instead with a date in the 1st century A.D. ${ }^{64}$ We have also observed that the writing of $\mathrm{irm}$ in Inscription C (see Commentary, note h) resembles Ptolemaic script, according to the Demotisches Glossar, and Malinine also felt that some writings in the shroud's inscriptions were "suggestive of Ptolemaic forms." ${ }^{65}$ Further, the other attestations of $\underline{d}-d h w t y-i w=f^{-} n h$ indicate that this name fell out of fashion after the Ptolemaic era. Taken together, this evidence seems to

\footnotetext{
${ }^{59}$ See also Demot. Nb. I, Lief. 18, 177.

${ }^{60}$ According to the references in the name index of Demot. Nb. I, Lief. 18.

${ }^{61}$ Thompson, A Family Archive from Siut.

${ }^{62}$ F. Lexa, Das demotische Totenbuch der Pariser Nationalbibliothek (Papyrus des Pa-Month) (Leipzig, 1910). New edition: M. A. Stadler, Der Totenpapyrus des Pa-Month (Studien zum altägyptischen Totenbuch 6) (Wiesbaden, 2002).

${ }^{63}$ G. Mattha, The Demotic Legal Code of Hermopolis West, BdE 45 (Cairo,1975). Most recent edition: K. Donker van Heel, The Legal Manual of Hermopolis [P. Mattha] (Leiden, 1990).

${ }^{64}$ See W. J. Tait, "Rush and Reed: The Pens of Egyptian and Greek Scribes," Proceedings of the XVIII International Congress of Papyrology, Vol. II, ed. B. G. Mandilaras (Athens, 1988), 477-81.

${ }^{65}$ D'Auria, Lacovara and Roehrig, Mummies and Magic, 205, citing Parlasca, Mumienporträts, 187.
} 
Table 1. Demotic Writings of Wepwawet

\begin{tabular}{|c|c|c|}
\hline Date & Asyut & Other provenances \\
\hline Early Demotic & P.Cairo 50060 III 14 & \\
\hline Middle Demotic & 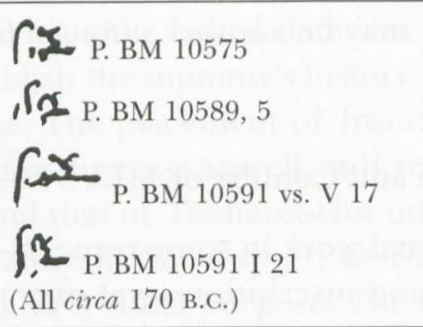 & $\begin{array}{l}\text { folldy P. BN } 218 \text {, witness list } 16 \\
\text { (Thebes, } 146 \text { B.C.) } \\
\text { (Thebes, } 146 \text { B.c.) }\end{array}$ \\
\hline Late Demotic & & $\int_{\text {Graffito Philae } 61,27}^{\prime}$ \\
\hline unclear & & 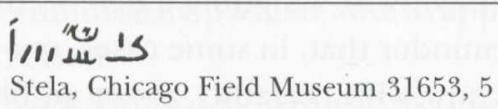 \\
\hline
\end{tabular}

prevent us from straying too far from the Ptolemaic Period in dating the shroud, inviting a date in the early 1st century A.D.

Prosopographic data from the shroud are unhelpful for dating purposes, since the woman, her father, and her husband cannot be linked to any other, well-dated material. As has been pointed out above (Commentary, note d), the Demotisches Namenbuch entry for the standard writing of $\underline{d}$-dhwty$i w=f$ - $n h$ misses out the instances in Inscription B, and the other references in the Namenbuch show that the standard writing is not otherwise attested in Demotic beyond the Ptolemaic Period, with the latest references again coming from the 2nd-century B.C. Asyut archive. ${ }^{66}$ None of the Demotic instances of men named $\underline{d}-\underline{d} h w t y-i w=f-n h$ can be connected with the two men mentioned on MFA 54.993 , nor can any other women named $t 3-5$ r.t-hr $r-w d \underline{d} 3$ be identified with the deceased woman on the shroud (see Demot. Nb. I 1140-41).

The apparent reference to a cult of Sarapis in Inscriptions B and C is also not a dating criterion for the shroud, though it may offer some insight into the perception of Sarapis in an Egyptian funerary context. As discussed above (see Commentary, note e), there is hardly any evidence for a Sarapis cult in Asyut, but the worship of Osiris is well attested at the site in sources dating up to, but not beyond, the end of the Ptolemaic Period. On the stela of Apollonios from Roman Abydos, which has been dated on palaeographic grounds to the first century A.D., the Greek inscription asks Sarapis to grant Apollonios from Lykopolis triumph over his enemies ${ }^{67}$ The Greek text appears below an Egyptian scene showing Apollonios burning incense before a standard with a jackal on top, i.e, the symbol for

${ }_{66}^{6}$ Thompson, A Family Archive from Siut, Text A, line 10 (pp. 40, 45); Text B, column x, line 18 (pp. 12, 33).

${ }^{67}$ Koemoth, "À propos de la stèle d'Apollônios" (n. 51). 
Wepwawet, and Osiris wearing the atef-crown combined with horns. Thus Sarapis is mentioned, but Osiris is depicted-a feature that recurs on other stelae from Roman Abydos. ${ }^{68}$ Although the stela seems to have been found at Abydos, it may have been made in Apollonios's home city of Asyut; at the very least, Apollonios's Lycopolite background would suggest that the gods mentioned and depicted on his stela were known in Roman Asyut. It is striking that even at Abydos, a dedication could express a prayer to Sarapis, rather than Osiris, a feature paralleled on a bilingual stela in Berlin (inv. 2133) whose Demotic inscription invokes "Osiris, the great god, the lord of Abydos" while the Greek refers to "the lord Sarapis." ${ }^{\circ 9}$ In the absence of evidence for a distinct cult of Sarapis at Asyut, the observed equivalence between Osiris and Sarapis suggests that the town's Osiris cult may have persisted in the Roman Period but used the god's "new" or additional name. Therefore the occurrence of wsir$h p$ "Sarapis" on MFA 54.993, instead of Osiris, may be another point in favor of a first century A.D., or later, date.

\section{Conclusion: The Date and Context of MFA 54.993}

The shroud of Ta-sheret-Hor-udja is an unusual work in some respects-its Asyut provenance, and the peculiarities of its portrait, iconography, and inscriptions-yet overall it is typical of the funerary art produced in Egypt from the end of the Ptolemaic Period through the Roman Period, encapsulating as it does the confrontation of conceptual Egyptian art and illusionistic Greek and Roman representations.

The difficulty of assigning a date to the shroud based on either its portrait or its palaeography is a useful reminder that, in some cases, our methodologies and the state of the ancient record limit what we can know with certainty about an object. Rather than being a barrier, however, this uncertainty can be an asset, inviting questions about the evidence that might not otherwise have been raised. For example, since the hairstyle of Ta-sheret-Hor-udja is not an accurate copy of Roman imperial hairstyle, in the way that most mummy portraits are, it is worth considering whether her hairstyle was based on an imperial model at all. Was the painter simply trying to convey an impression of fashionable hair, to fit the mode of the portrait? If the hairstyle was meant to copy a Roman fashion, what sources did painters use to copy fashionable coiffures? What if the source was a profile view, like a coin, or an image of a veiled empress, where part of the hairstyle was obscured? Is Ta-sheret-Horudja's hairstyle instead peculiar to her or to the region of Asyut?

These questions remain open, as does the specific dating of the shroud. Roman comparanda for the hairstyle could variously support a Julio-Claudian (early first century A.D.), Antonine (mid-second century A.D.), or Severan (late second century A.D.) date. The jewelry and white mantle suggest a late first or early second century date, and the pose, reconstructed with a hand garland, finds a parallel in a Julio-Claudian shroud (see n. 15) and on mummy masks from much of the Roman Period. The palaeography of the Demotic inscriptions cannot help pinpoint a date because of the lack of comparable Demotic texts from Asyut, not to mention the problems inherent in comparing writing on a textile to writing on other materials. Although the apparent use of a reed pen for the inscriptions helps confirm that the shroud is Roman, the inscriptions' references to year 4 could refer to almost any imperial reign. The name shared by Ta-sheret-Hor-udja's father and husband, Dje-Djehuty-iu-ef-ankh, might favor a first-century date for the shroud if other Egyptian sources accurately reflect that this

68 A. Abdallah, Graeco-Roman Funerary Stelae from Upper Egypt (Liverpool, 1992), 61 (no. 148, CG 9208), 62 (no. 151 , CG 9211), 70 (no. 173, CG 9213); see also J. G. Milne, Greek Inscriptions (Oxford, 1977), 63 (CG 9213), $65-66$ (CG 9208 ), 67 (CG 9211), with images on pls. 10 and 11.

69 Abdallah, Graeco-Roman Funerary Stelae, 77 (no. 189); see also Koemoth, “À propos de la stèle d'Apollônios,” 229. 
name fell out of use in Roman times, which would suggest that both men were probably born in or around the end of the Ptolemaic Period. The idea that the shroud of Ta-sheret-Hor-udja dates to the first century A.D., as MFA curators originally believed, is thus a viable alternative to the Severan date that has more recently been accepted, but neither date can be proved beyond doubt at this point.

The inscriptions leave no doubt, however, that the subject of the shroud was a woman with an Egyptian name and parentage, whose father was active in the most important local priesthood. Designating her as a "Hathor" heralded the transfiguration of dead women and girls in the afterlife and was standard in Roman Egypt, culminating a development that began in the Late Period, if not earlier. ${ }^{70}$ The date recorded in Inscriptions A and C-year 4, month 3, day 14-seems to record the day of Ta-sheret-Hor-udja's actual burial, rather than her death, and the inscriptions function like an identifying ticket or docket. Perhaps the burial date was of interest to the necropolis workers for their record-keeping and to establish the mummy's history, if it were being placed in a tomb that would be re-used or visited over time. The placement of Inscription B above the image of a reborn mummy suggests another function for the texts as well, as if to strengthen the connection between the fate of the represented mummy and that of Ta-sheret-Hor-udja herself. The repetition of information in the inscriptions is a curious feature in this respect, as if one had to be added after the other for clarity, confirmation of the details, or a ritual purpose. The inscriptions might help reconstruct the appearance of the original mummy as well: If any or all of them were written on the shroud once it was in place on the mummy, these portions of the textile must not have been hidden by any other wrappings. Further, given its position near the decorated edge of the shroud, Inscription $\mathrm{C}$ would only have been visible if the mummy had a large girth, like the voluminously padded and wrapped mummies attested elsewhere in Middle Egypt during the Roman Period. ${ }^{71}$

Naturalistic portraits derived from Greek and Roman art had a widespread appeal, as did changing fashions in dress, jewelry, and hairstyles. The inclusion of such features in an Egyptian funerary context does not correlate to the lineage of the deceased but to the desirability of these modes for selfpresentation. The local elites of Egyptian towns exploited both Greek and Egyptian forms of art and knowledge, and naturalistic portraiture was a novel, attractive way in which to be depicted. From the inscriptions of her shroud, we know that Ta-sheret-Hor-udja was of Egyptian descent, from a family whose involvement with the local cults of Asyut probably contributed to her social status and to her careful burial. The appearance of her portrait does not contradict her Egyptian heritage or the traditions embodied by her burial and by the Egyptian registers of MFA 54.993. The portrait, the registers, and the inscriptions together make up the shroud and make it a testament to the interests and aspirations of the priestly class in Roman Egypt.

The Manchester Museum and University of Würzburg

\footnotetext{
${ }^{70}$ M. Smith, The Mortuary Texts of Papyrus BM 10507, Catalogue of Demotic Papyri in the British Museum, III (London, 1987), 129-31.

${ }^{71}$ E.g. the mummy of Artemidora from Meir (n. 3).
} 